\title{
Vascular Endothelial Growth Factor Gene Polymorphisms in Women who Experienced Repeated Pregnancy Losses
}

\author{
PAUL TUTAC ${ }^{1 \#,}$ NOEMI MESZAROS ${ }^{2 \#}$, NICOLETA ANDREESCU ${ }^{1 *}$, \\ SIMONA FARCAS ${ }^{1}$, ANDREEA IULIA DOBRESCU ${ }^{1}$, DANIELA AMZAR ${ }^{3}$, \\ MARIA PUIU ${ }^{1}$ \\ ${ }^{1}$ Genetics Discipline, Center of Genomic Medicine, University of Medicine and Pharmacy "Victor Babes" Timisoara \\ ${ }^{2}$ Life Science Department, Vasile Goldis Faculty of Medicine, Arad, Romania \\ ${ }^{3}$ Endocrinology Discipline, University of Medicine and Pharmacy "Victor Babes" Timisoara
}

\begin{abstract}
The well accepted causes of pregnancy loss are chromosomal anomalies, uterine anomalies, thrombophilic and immune disorders and endocrine dysfunction. During early gestation, VEGF is essential for the maturation of oocytes, the proliferation of trophoblasts, the implantation and development of the embryo, the angiogenesis of the placenta, and the growth of maternal and fetal blood vessels in the uterus. The aim of this study is to establish the incidence of -634G/C VEGF polymorphism in our study lot that included women with recurrent miscarriages as well a comparation with the incidence of the same polymorphism in a control lot of subjects with no reproduction faillure history. The study lot included 35 women with multiple pregnancies losses, aged between 18 and 41 years old. The control lot consists of 59 healthy individuals that had no experience of reproductive failure. Genotyping of $-634 G / C$ VEGF was done for both study and control lots. We found a significant statistic difference of the alleles frequencies between the two tested cohorts, the study lot and the control lot. Further studies should focus on testing VEGF variants in women that experience repeated pregnancy losses in order to establish an association among VEGF polymorphisms, endometrial VEGF expression and plasma VEGF levels in RPL patients.
\end{abstract}

Keywords: VEGF, pregnancy loss, regulator, rs2010963, Real-Time PCR, protein

\section{Introduction}

Repeated pregnancy loss is reported in about $0.5-2 \%$ of the women in reproductive age [1]. The most known causes of pregnancy loss are chromosomal anomalies, uterine anomalies, thrombophilia and immune disorders and endocrine dysfunction [1-4]. Still the cause of pregnancy loss can not be elucidated in more than 50\% of all miscarriages [5]. Currently, more attention is paid to evaluation of vascular mechanisms that can play an important role in embryo implantation and placental development [6]. An inappropriate angiogenesis may lead to implantation failure or inadequate placental development after zygote implantation [7].

Vascular endothelial growth factor (VEGF) is a prime regulator (specific protein) of angiogenesis of vascular endothelial cells and vasculogenesis, a very important protein implicated in the implantation of the embryo $[8,9]$. VEGF is an angiogenic factor which behaves by remodeling and improving the vascular growth, as well as by rising vessel permeability, which is decisive for the embryo implantation and later on the process of evolution of the placenta [10].

VEGF family and their receptors ligands are known as strong angiogenic agents secreted by placenta, endometrium and decidua [11]. VEGF is very abundant expressed in placenta syncytiotrophoblast and trophoblast cells during pregnancy and plays a serious role in normal embryonic development as in hematopoiesis, bone formation, chronic inflammation or wound healing [12-14]. 
Angiogenesis and also vasculogenesis are critical for fertilized egg implantation and placentation $[8,10]$. During early gestation, VEGF is essential for the maturation of oocytes, the proliferation of trophoblasts, the implantation and development of the embryo, the angiogenesis of the placenta, and the growth of maternal and fetal blood vessels in the uterus [15].

If there occurs a decrease in blood flow, epithelial cell growth and VEGF production can be reduced, which will deprive the endometrium of necessary angiogenesis and growth factors to achieve just thickness for remarkable implantation [16].

There are studies reporting an association between altered expression of VEGF and unfavorable pregnancy outcomes, including preterm birth, pre-eclampsia, intrauterine growth restrain, and spontaneous abortion [17].

Several genetic studies testing associations of VEGF variants as genetic decisive factors in the development of recurrent pregnancy losses (RPL) have revealed conflicting results [18].

\section{Aim}

The aim of this study is to establish the incidence of -634G/C VEGF polymorphism in our study lot that included women with recurrent miscarriages as well a comparison with the incidence of the same polymorphism in a control lot of subjects with no reproductive failure history.

\section{Material and method}

This study was performed in the Center for Genomic Medicine affiliated to University of Medicine and Pharmacy "Victor Babes" Timisoara. The study lot included 35 women with multiple pregnancies losses, aged between 18 and 41 years old. We noted the age of each patient, gravidity, parity, previous abortions, and live births, as well as the gestational age of the last miscarriage. The exclusion criteria were: patients with known cause of miscarriage, cases with cytogenetic fetal anomalies, carriers of chromosomal aberrations, women with chronic or acute immune/infectious diseases or uterine anomalies.

The control lot consists of 59 healthy individuals that had no experience of reproduction failure.

We collected $2 \mathrm{~mL}$ of peripheral blood in K2 EDTA 2 vacutainers for DNA extraction from the women included in the study lot as well as for the control lot. DNA isolation was performed according to the protocol provided by the manufacturer, by using the MagCore Automatic Nucleic Acid Extractor and the MagCore Genomic DNA Whole Blood Kit (RBC Bioscience). DNA concentrations and DNA purity were evaluated before proper testing to ensure a balanced quantity-quality ratio. DNA samples were stored at $-80^{\circ} \mathrm{C}$.

Genotyping of VEGF (-634G/C)(rs2010963)(C_8311614_10) was done for both study and control cohorts. Allelic discrimition was performed by using a TaqMan Genotyping Assay (Applied Biosystems) and TaqMan Master Mix (Applied Biosystems) according to manufacturer protocol. Allelic discrimination was carried out on QuantStudio 7 Real-Time PCR System (Applied Biosystems) with the following parameters: $95^{\circ} \mathrm{C}$ for $10 \mathrm{~min}, 40$ cycles of $92^{\circ} \mathrm{C}$ for $15 \mathrm{~s}$ and $60^{\circ} \mathrm{C}$ for $1 \mathrm{~min}$. VEGF genotypes were determined by measuring allele-specific fluorescence using the QuantStudio 7 software for allelic discrimination (Applied Biosystems).

Statistical analysis was done by using IBM SPSS Statistics 23. The Student's t-test in conjunction with the chi-square test were used to verify the significance between variables. The values were considered significant if $\mathrm{p}<0.05$.

\section{Results and discussions}

The study group included 35 females with pregnancy loss aged between 18-41 years, with median age of $31,82 \pm 5,38$. Descriptive statistic is shown in Table 1 . 
Table 1. Descriptive statistics for the study lot

\begin{tabular}{|c|c|c|c|c|c|}
\hline & $\mathrm{N}$ & Minimum & Maximum & Mean & Std. Deviation \\
\hline Maternal Age & 35 & 18.0 & 41.0 & 31.829 & 5.3824 \\
\hline Number of pregnancies & 35 & 1.0 & 5.0 & 2.057 & 1.0556 \\
Valid N (listwise) & 35 & & & & \\
\hline
\end{tabular}

The study lot includes females with one, two, tree, four or a maximum of 5 pregnancy losses. We sumed the number of pregnancies and number of abortions to see the exact ratio outcome. These 35 females totals 73 pregnancies and 71 pregnancies losses with a ratio of 0.97 .

We found three genotypes for both study and control lot: GG, GC and CC. We tested the -634G/C VEGF genotype frequencies for both study and control lots, the results being presented in Table 2 .

Table 2. VEGF genotype frequencies

\begin{tabular}{|c|c|c|c|c|c|}
\hline \multicolumn{6}{|c|}{ VEGF Genotype for study lot } \\
\hline & & Frequency & Percent & Valid Percent & Cumulative Percent \\
\hline \multirow[t]{4}{*}{ Valid } & GG & 3 & 5.1 & 8.6 & 8.6 \\
\hline & GC & 16 & 27.1 & 45.7 & 54.3 \\
\hline & $\mathrm{CC}$ & 16 & 27.1 & 45.7 & 100.0 \\
\hline & Total & 35 & 100.0 & 100.0 & \\
\hline \multicolumn{6}{|c|}{ VEGF Genotype for control lot } \\
\hline \multirow[t]{4}{*}{ Valid } & GG & 15 & 25.4 & 25.4 & 25.4 \\
\hline & GC & 28 & 47.5 & 47.5 & 72.9 \\
\hline & $\mathrm{CC}$ & 16 & 27.1 & 27.1 & 100.0 \\
\hline & Total & 35 & 100.0 & 100.0 & \\
\hline
\end{tabular}

By comparing genotype frequencies in the study lots we found that the most frequent genotypes are GC (45.7\%) and CC (45.7\%), equally represented; while in the control lot the most frequent genotype was GC (47.5). We observed a statistically significant difference between genotype frequencies in study and control lot $(\mathrm{p}=0.007)$.

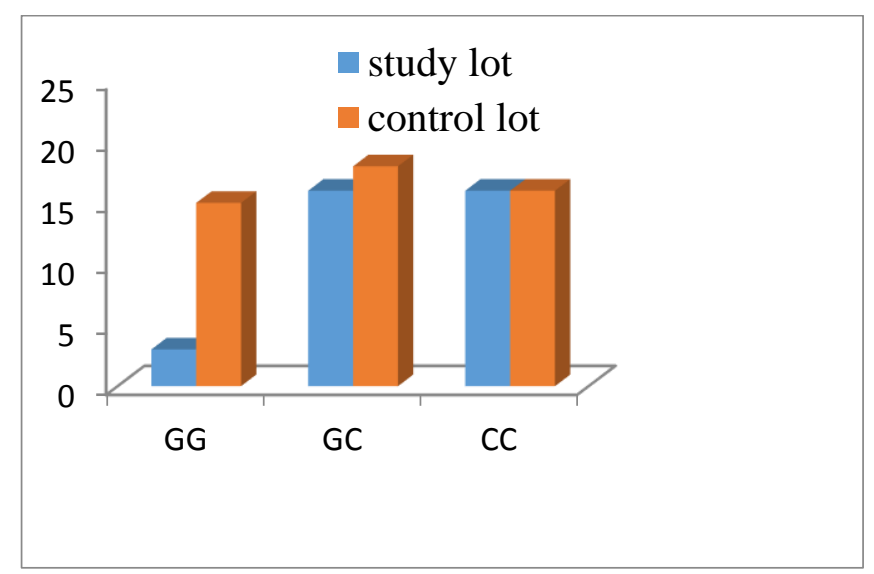

Figure 1. VEGF genotypes distribution in the study and in control lots

We found a statistically significant difference between the VEGF frequency of the genotypes for the study group: GG (8.6\%), GC (45.7\%) and CC (45.7\%) ( $\mathrm{p}=0.008)$. 


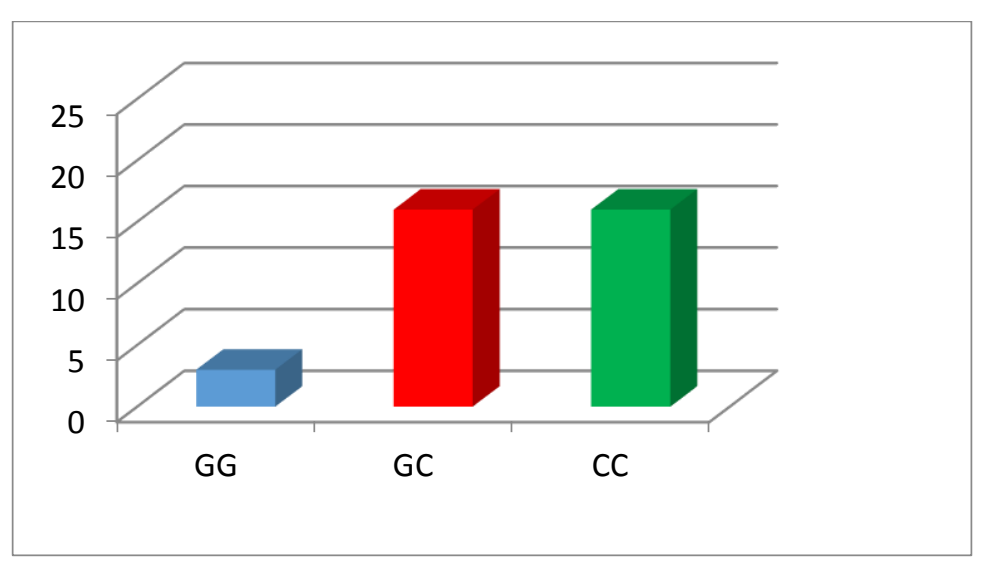

Figure 2. VEGF genotypes distribution on the study lot

VEGF genotypes frequencies in the control lot were: GG (25.4\%), GC (47.5\%) and CC (27.1\%) and shown no statistical significance $(\mathrm{p}=0.07)$.

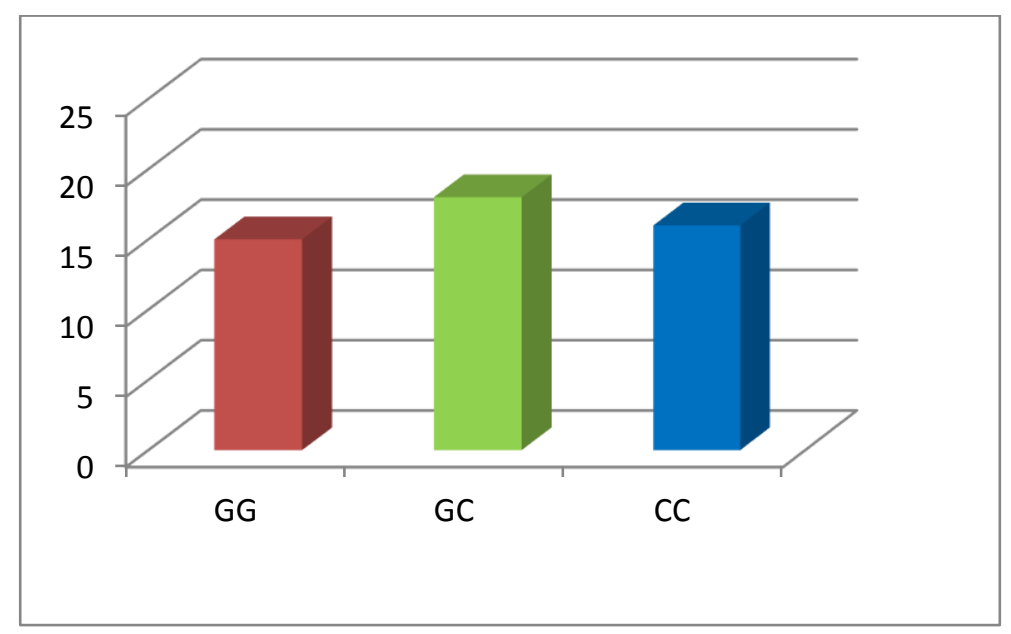

Figure 3. VEGF genotypes distribution on the control lot

Repeated miscarriage is one of the major challenges that reproductive medicine faces due to the multiple causative factors. Therefore, the identification of genetic variants that predispose to repeated pregnancy loss opens new research area to improve the reproductive fitness for these patients [19].

Determining optimal vascularization and placental blood flow it's critical for successful pregnancy result [20]. There is evidence showing that VEGF could participate in the ovulation cycle, more exactly in follicles development, which would lead to premature birth and recurrent miscarriage [21].

VEGF gene have an important role in vasculogenesis and angiogenesis. Deregulated VEGF expression contributes to the development of several diseases that are characterized by abnormal angiogenesis. Serum VEGF was significantly higher in patients with vascular malformations, compared with controls [22]. The importance of identifying vascular malformations prior to radiological or surgical intervention is necessary in order to prevent possible complications [23-24].

VEGF is essential for placental trophoblast proliferation and differentiation, the development of embryo vascularization, and growth of maternal and fetal blood cells in utero. Diminished placental trophoblastic VEGF expression was linked with heightened risk of spontaneous miscarriages [19].

There are several studies that evaluate a posible correlation between VEGF genotype and RPL [1516]. One specifically study ended with the assumption that VEGF contributes to successful implantation and support of pregnancy by rising vascular permeability in the decidua [17].

We found only a few manuscripts regarding the role of $-634 \mathrm{G} / \mathrm{C}$ VEGF gene variant in reproduction failure. We found contradictory results regarding a posible correlation between VEGF 
variants and pregnancy loss as well as data about the incidence of those variants on specific populations, with no possibility to extend the conclusion for the general population.

A recent meta-analysis by Zhang et al. suggested that $-634 \mathrm{G} / \mathrm{C}$ VEGF gene variant was associated with an increased risk of RPL under specific genetic models. Another study showed that $-634 \mathrm{G} / \mathrm{C}$ allele increased the risk of RPL in the codominant model ( $\mathrm{C}$ vs. $\mathrm{G}$ : $\mathrm{OR}=1.16, \mathrm{p}=0.01)$, homozygous comparison ( $\mathrm{CC}$ vs. GG: $\mathrm{OR}=1.36, \mathrm{p}=0.02)$, and the recessive model $(\mathrm{CC}$ vs. $\mathrm{GC}+\mathrm{GG}$ : $\mathrm{OR}=0.79, \mathrm{p}$ $=0.04$ ), but without any significant associations found between the heterozygous and dominant models [25]. Due to very little data, there was no solid concusion drawn, and other studies need to confirm these results [25].

Our results are in line with those obtained on the Russians populations in a study in which -634G/C VEGF gene variant was associated with increased tendency to RPL during pregnancy. [2627].

A good point of view for the improvement of placental development, is shown in the studies of the intake of Aspirin in women with RPL. Meta-analysis of low-dose aspirin to prevent pre-eclampsia suggest that the incidence of preterm birth might be decreased, particularly if initiated before 14-16 weeks of gestation with $150 \mathrm{mg}$ of aspirin [28-29].

Our study has several limitations that should be taken into account. First, the sample size was relatively small, which may lead to a lack of sufficient statistical power in order to estimate the role of $-634 G / C$ VEGF variant in RPL. Therefore, further studies on a larger cohort is still needed. Second, we did not provide a direct evidence in order to support our hypothesis regarding the implication of $-634 \mathrm{G} / \mathrm{C}$ VEGF variant in RPL. Third, we did have no records of VEGF plasma level nor about the endometrium VEGF expression in our study and control lots.

\section{Conclusions}

We found a significant statistical difference of the alleles frequencies between the two tested cohorts, the study lot and the control lot. We also found a statistical significance between VEGF frequency of the genotypes for the study group. We conclude that $-634 \mathrm{G} / \mathrm{C}$ VEGF gene variant might be correlated with an increased risk of repeated pregnancy losses. Further studies should focus on testing VEGF variants in women that experience repeated pregnancy losses in order to establish an association among VEGF polymorphisms, endometrial VEGF expression and plasma VEGF levels in RPL patients.

Acknowledgments. This research was done in the Center of Genomic Medicine from the "Victor Babeş" University of Medicine and Pharmacy, Timişoara, POSCCE Project ID: 1854, cod SMIS: 48749, "Center of Genomic Medicine v2", contract 677/09.04.2015.

\section{References}

1. ATALAY, M.A., UGURLU, N., ZULFIKAROGLU, E., DANISMAN, N., Clinical significance of maternal serum vascular endothelial growth factor (VEGF) level in idiopathic recurrent pregnancy loss, Eur. Rev. Med. Pharmacol. Sci. 20(14), 2016, 2974-82.

2. FARCAS S., CRIŞAN C.D., ANDREESCU N., STOIAN M., MOTOC A. G. M., Structural chromosomal anomalies detected by prenatal genetic diagnosis: our experience, Rom. J. Morphol. Embryol. 54(2), 2013, 377-383.

3. ANDREESCU N.I., COSMA M., FARCAS S.S., STOIAN M., AMZAR D.G., PUIU M., Assessment of chromosomal aneuploidies in sperm of infertile males by using FISH technique, Rom. J. Morphol. Embryol. 57(1), 2016, 173-178.

4. ERDELEAN D., FARCAS S.S., POROCH V., ANDREESCU N.I., ERDELEAN I., DOBRESCU A.I., NUSSBAUM L.A., HOGEA L.M., NAVOLAN D., TUTAC P., PUIU M, Association Between Thrombophilia Gene Polymorphisms and Recurrent Pregnancy Loss, Rev. Chim., 69,(11), 2018, 3122 
5. SARAVELOS, S.H., REGAN, L., Unexplained recurrent miscarriage: how can we explain it? Obstet. Gynecol. Clin. North. Am., 41(1), 2014, 157-66.

6. CHOI H.-K., CHOI B.C., LEE S.-H., KIM J.W., CHA K.Y., BAEK, K-H., Expression of angiogenesis- and apoptosis-related genes in chorionic villi derived from recurrent pregnancy patients., Mol Reprod Dev., 66(1), 2003, 24-31.

7. FARQUHARSON, R.G., JAUNIAUX, E., EXALTO, N, Updated and revised nomenclature for description of early pregnancy events, Hum. Reprod., 20, nr. 11, 2005, p. 3008-11.

8. OLSSON, A.-K., DIMBERG, A., KREUGER, J., CLAESSON-WELSH, L., VEGF receptor signalling ? in control of vascular function. Nat. Rev. Mol. Cell. Biol., 7(5), 2006, 359-371.

9. NEUFELD, G., COHEN, T., GENGRINOVITCH, S., POLTORAK, Z., Vascular endothelial growth factor (VEGF) and its receptors. FASEB. J. Off Publ. Fed. Am. Soc. Exp. Biol., 13(1), 1999, p. $9-22$.

10. TURIENZO, A., LLEDÓ, B., ORTIZ, J.A., MORALES, R., SANZ, J., LLÁCER, J., Prevalence of candidate single nucleotide polymorphisms on p53, IL-11, IL-10, VEGF and APOE in patients with repeated implantation failure (RIF) and pregnancy loss (RPL). Hum. Fertil., 2018, 1-6.

11. GHOSH, S., JANA, K., MANDAL, P., CHAKRABARTY, T., BHATTACHARYA, D., GHOSH, T.K., Detection of Serum Vascular Endothelial Growth Factors (VEGF) And Soluble Vascular Endothelial Growth Factors (sVEGF/sflt-1) of Pregnancy Induced Hypertension Mothers (PIH) With pathological changes of Placenta In a Tertiary Care Hospital of West Bengal.Int. J. Hum. Health Sci. IJHHS., 2(1), 2018, 25-30.

12. TANG, Y., YE, W., LIU, X., LV, Y., YAO, C., WEI, J., VEGF and sFLT-1 in serum of PIH patients and effects on the foetus. Exp. Ther. Med., 17(3), 2019, 2123-2128

13. SHERBET, G.V., Growth Factors and Their Receptors in Cell Differentiation, Cancer and Cancer Therapy. Elsevier, 2011, 368.

14. DUFFY, A.M., BOUCHIER-HAYES, D.J., HARMEY, J.H., Vascular endothelial growth factor (VEGF) and its role in non-endothelial cells: autocrine signalling by VEGF. VEGF Cancer, 2004, 133-144.

15. BASHIRI, A., HALPER, K.I., ORVIETO, R., Recurrent Implantation Failure-update overview on etiology, diagnosis, treatment and future directions. Reprod. Biol. Endocrinol., 16(1), 2018, 121.

16. HASHEMI, M., DANESH, H., BIZHANI, F., MOKHTARI, M., BAHARI, G., TABASI, F., The2549 insertion/deletion polymorphism in the promoter region of VEGF is associated with the risk of recurrent spontaneous abortion. Biomed. Rep., 8(3), 2018, 297-300.

17. JUNG. Y.W., AHN, E.H., KIM, J.O., AN, H.J., CHO, S.H., KIM, Y.R., Association of genetic polymorphisms in VEGF-460,-7 and-583 and hematocrit level with the development of idiopathic recurrent pregnancy loss and a meta-analysis. J. Gene Med., 20(9), 2018, 3048.

18. KAPITEIJN, K., KOOLWIJK, P., VAN DER WEIDEN, R.M., VAN NIEUW AMERONGEN, G., PLAISIER, M., VAN HINSBERGH, V.W., Human embryo-conditioned medium stimulates in vitro endometrial angiogenesis. Fertil. Steril., 85, 2006, 1232-1239.

19. GANNOUN, M.B.A., AL-MADHI, S.A., ZITOUNI, H., RAGUEMA, N., MEDDEB, S., ALI, F.H.B., Vascular endothelial growth factor single nucleotide polymorphisms and haplotypes in preeclampsia: A case-control study. Cytokine, 97, 2017, 175-180.

20. CHEN, H., ZHENG, J.-B., WANG, D.-M., XING, H., WANG, H., Association between Vascular Endothelial Growth Factor and Clinical Outcomes of IVF-ET/ICSI J. Coll. Physicians Surg. Pak., 29(1), 2019, 19-23.

21. XU, X., DU, C., LI, H., DU, J., YAN, X., PENG, L., Association of VEGF genetic polymorphisms with recurrent spontaneous abortion risk: a systematic review and meta-analysis. PLoS One, 10(4), 2015.

22. EL-RAGGAL, N.M., EL-FARRASH, R.A., SAAD, A.A., ATTIA, E.A.S., SAAFAN, H.A., SHAABAN, I.S., Circulating levels of vascular endothelial growth factor and basic fibroblastic growth 
factor in infantile hemangioma versus vascular malformations. Clin. Appl. Thromb. Hemost., 24(4), 2018, 663-668.

23. MATUSZ, P., MICLĂUŞ, G.D., GABRIEL, A., CATERENIUC, I., OLARIU, S., TUBBS, R.S., LOUKAS, M. Single ectopic thoracic renal artery associated with a normal kidney position and renal artery stenosis: a case report and review of literature Rom. J. Morphol. Embryol., 56(2), 2015, 557-562.

24. IOANOVICIU, S.D., IVAN, C., MATUSZ, P.,OLARIU, S.,LIGHEZAN, D., Morphological Variability of the Hepatic Portal Vein Posterior Branch: Study on Corrosion CastsMater. Plast., 52(2), 2015, 263-265.

25. ZHANG, B., DAI, B., ZHANG, X., WANG, Z., Vascular endothelial growth factor and recurrent spontaneous abortion: a meta-analysis. Gene, 507(1), 2012, 1-8.

26. TRIFONOVA, E.A., SWAROVSKAYA, M.G., GANZHA, O.A., VORONKOVA, O.V., GABIDULINA, T.V., STEPANOV, V.A., The interaction effect of angiogenesis and endothelial dysfunction-related gene variants increases the susceptibility of recurrent pregnancy loss. J. Assist. Reprod. Genet., 2019, 1-10.

27. STOICA, F., IONESCU, D., HEGHES, A., TRANDAFIRESCU, C., ANDREESCU, N., TUDOR A., OLARIU, S., STANCIU, A., GALEA, M., PUIU, M., Vascular Endothelial Growth Factor Gene Polymorphism - Susceptibility Predictor for Severe Retinopathy of Prematurity? Rev. Chim., 67, (12), 2016.

28. HOFFMAN, M. K., GOUDAR. S. S., KODKANY B. S., ET ALL., Low-dose aspirin for the prevention of preterm delivery in nulliparous women with a singleton pregnancy (ASPIRIN): a randomised, double-blind, placebo-controlled trial, Lancet. 2020, 285-293.

29. ZVANCA, M. E., BOT, M., RADU, N., PETCA, A., Impact of early supplementation with lowdose aspirin on functional first trimester parameters in low-risk pregnancies, J Matern Fetal Neonatal Med., 32(4), 2019, 604-609.

Manuscript received: 8.11.2019 